\title{
KADAR ENZIM TRANSAMINASE (SGPT, SGOT) DAN GAMMA GLUTAMYL TRANSPEPTIDASE $(\gamma$-GT) PADA AYAM PETELUR FASE LAYER YANG DIBERI EKSTRAK PEGAGAN (Centella asiatica)
}

\section{Transaminase (SGPT, SGOT) and Gamma Glutamyl Transpeptidase ( $\Gamma$-Gt) Levels in Phase Layer Day Chicken With Pegagan Extract (Centella Asiatica)}

\author{
Aila Jiwandini ${ }^{1}$, Handi Burhanudin ${ }^{2}$, Andi Mushawwir ${ }^{2}$ \\ ${ }^{1}$ Program Studi Ilmu Peternakan, Fakultas Peternakan, Universitas Padjadjaran \\ Kampus Jatinangor, Jl. Raya Bandung-Sumedang KM.21, Jatiangor, Sumedang, \\ Jawa Barat 45363 \\ ${ }^{2}$ Laboratorium Fisiologi Ternak dan Biokimia, Departemen Nutrisi Ternak dan Teknologi \\ Pakan, Fakultas Peternakan, Universitas Padjadjaran, Bandung \\ Kampus Jatingaor, Jl. Raya Bandung- Sumedang KM.21, Jatiangor, Sumedang, \\ Jawa Barat 45363
}

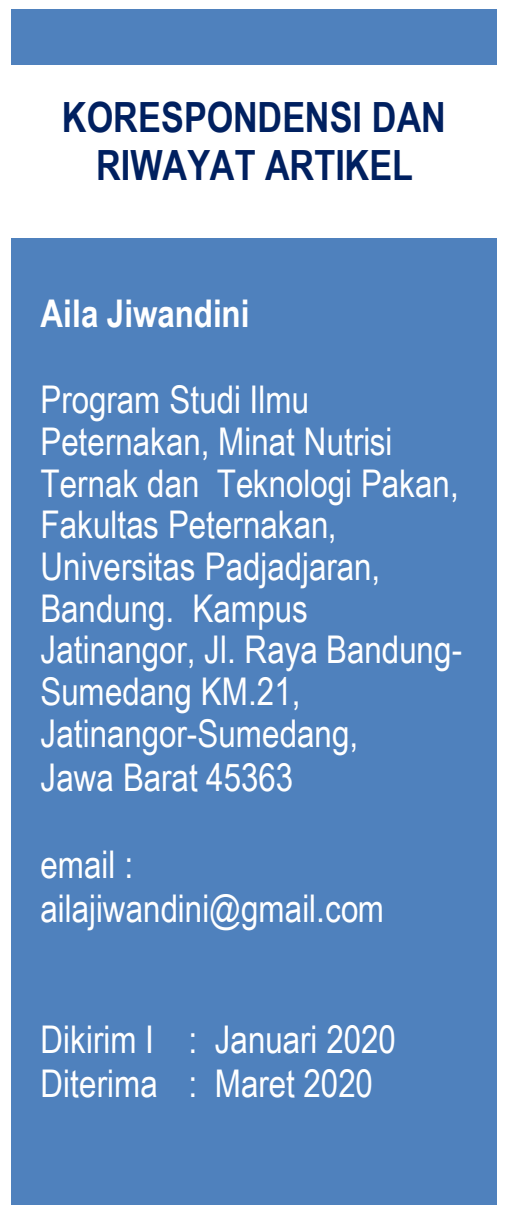

\begin{abstract}
ABSTRAK
Hepar sebagai organ kelenjar terbesar memiliki peran penting dalam metabolisme glukosa dan lipid, membantu proses pencernaan, absorbsi lemak dan vitamin yang larut dalam lemak, serta detoksifikasi tubuh terhadap zat toksik. Mengingat pentingnya fungsi hati dalam tubuh maka perlu dilakukan control terhadap fungsi hati untuk mengoptimalisasi produktivitas ternak. Penurunan produktivitas ayam petelur salah satunya dapat dipengaruhi oleh penurunan fungsi hati . Penelitian ini dilakukan untuk mengetahui aktivitas ekstrak pegagan (Centella asiatica) sebagai hepatoprotektor dengan menurunkan kadar enzyme SGOT,SGPT dan $\gamma$-GT dalam darah ayam petelur sebagai indicator kesehatan fungsi hati . Penelitian ini menggunakan 20 ekor ayam petelur umur 120 minggu dengan metode RAL (rancangan acak lengkap ) 4 perlakuan 5 ulangan. Perlakuan tersebut adalah P0 kontrol ransum basal tanpa penambahan ekstrak pegagan ; $\mathrm{P} 1$ ransum basal $+0,04 \%$ ekstrak pegagan ; $\mathrm{P} 2$ ransum basal $+0,08 \%$ ekstrak pegagan, $\mathrm{P} 3$ ransum basal $+0,12 \%$ ekstrak pegagan. Berdasarkan hasil analisis statistik menunjukkan bahwa pemberian ekstrak pegagan memberikan berbeda nyata $(\mathrm{p}<0,05)$ pada jumlah SGOT SGPT dan $\gamma$-GT.
\end{abstract}

Kata kunci : Ayam petelur, pegagan, transaminase dan $\gamma$-GT 


\section{ABSTRACT}

Liver is one of the largest glandular organs in laying hens handling some important roles in the process of glucose and lipid meatabolism, digestion, fat and soluble vitamins absorption, and body detoxification against toxics. Considering those crucial function of the liver, it is necessary to control it since the liver perfomance contributes to the decreased productivity of the laying hens. Thus, this research was aimed to determine activity of Centella asiatica extract as a hepatoprotector through reducing levels of SGOT, SGPT and $\gamma$-GT enzymes in blood of laying hens which can be an indicator of a healthy liver function. 20 laying hens aged 120 weeks were chosen by using CRD method (completely randomized design) and assigened by 4 treatments 5 replications. The treatments include $P O$ control of basal ration without the addition of gotu kola extract; P1 basal ration $+0.04 \%$ gotu kola extract; P2 basal ration + $0.08 \%$ gotu kola extract, P3 basal ration $+0.12 \%$ gotu kola extract. Based on statistical analysis, it showed that the administration of gotu kola extract gave significant differences ( $p$ $<0.05)$ on the amount of SGOT SGPT and $\gamma-G T$.

Keyword: laying hens, centella asiatica, transaminase and $\gamma$-GT

\section{PENDAHULUAN}

Ayam petelur afkir merupakan ayam yang mengalami kemunduran atau tidak mampu lagi untuk memproduksi telur. Ayam petelur ketika umurnya sudah semakin tua lebih dari 90 minggu dan telah melewati masa produktifnya, maka jumlah telur yang dihasilkan akan semakin menurun. Penurunan kemampuan produksi dapat disebabkan karena adanya penurunan fungsi organ tubuh ayam seiring dengan bertambahnya umur ternak. Penurunan produktivitas ayam ini kemudian dapat diupayakan dengan pemberian zat aktif untuk menjaga kondisi fisiologis tubuh ternak agar produksi telur tetap optimal. Salah satu fungsi organ penting yang diperlukan dalam menjamin keberlangsungan metabolisme didalam tubuh ternak adalah hati.

Hati/Hepar memiliki peran yang sangat penting dalam aktivitas di dalam tubuh seperti metabolisme glukosa dan lipid, membantu proses pencernaan, absorbsi lemak dan vitamin yang larut dalam lemak, serta detoksifikasi terhadap zat toksik. Mengingat peran hati yang sangat penting, maka kesehatan dan fungsi organ hati dalam tubuh ternak perlu diperhatikan untuk optimalisasi metabolisme dalam tubuh ternak. Hati yang sehat dan berfungsi optimal diharapkan dapat memperpanjang usia produktif ayam petelur.

Kesehatan dan fungsi hati dapat diukur dengan beberapa cara salah satunya dengan mengukur kadar enzim dalam darah. Beberapa enzim yang dapat menjadi indikator kinerja hati adalah kadar enzim transaminase dan gamma glutamyl transpeptidase $(\gamma-\mathrm{GT})$. Serum Glutamik Oksaloasetik Transaminase (SGOT) dan Serum Glutamik Pyruvik Transaminase (SGPT) merupakan dua enzim transaminase yang paling sering berkaitan dengan kerusakan hepatoselular.

Gangguan fungsi hati disebabkan oleh beberapa faktor, diantaranya radikal bebas dalam tubuh. Seiring bertambahnya usia ayam akan mengalami penurunan fungsi organ dapat disebabkan oleh degenerasi sel yang bertambah. Radikal bebas hadir sebagai konsekuensi dari adanya metabolisme dalam tubuh yaitu produk sampingan dari proses pembentukan energi. Mushawwir dan Latipuddin (2013) menunjukkan produksi radikal bebas yang semakin tinggi seiring dengan peningkatan temperatur lingkungan, keadaan ini lebih diperparah jika disertai dengan peningkatan kelembaban udara lingkungan kandang. Produksi radikal bebas yang melebihi kapasitas antioksidan yang ada, maka akan mengarahkan sel menuju 
stress oxidative, apoptosis, atau nekrosis termasuk pada sel hati.

Salah satu yang tergangu akibat adanya degenerasi dinding sel oleh radikal bebas adalah gangguan fungsi tarsportasi oleh $\gamma$-GT dan ganggan proses trasnaminasi (pembentukan asam amino) oleh enzyme transaminase dalam sel hati. Akibatnya kedua enzyme spesifik ini akan disekresikan dari sel hati ke dalam darah. Sehingga kadarnya meningkat dalam darah. Maka dari itu kadar enzim transaminase dan $\gamma$-GT yang tinggi didalam darah dapat menjadi indikator gangguan fungsi hati.

Hepatoprotektor adalah senyawa atau zat berkhasiat yang dapat melindungi sel-sel hati terhadap pengaruh zat toksik yang dapat merusak hati. Senyawa tersebut bahkan dapat memperbaiki jaringan hati yang fungsinya sedang terganggu. Biasanya hepatoprotektor merupakan bahan yang memiliki sifat antioksidan sehingga dapat mengurangi reaksi oksidasi pada kerusakan hati (Dalimartha, 2006).

Pegagan merupakan salah satu jenis tanaman didalamnya terkandung banyak zat aktif yang dapat memelihara kesehatan. Beberpa zat bioaktif diantaranya yaitu asiaticosida, polifenol triterpenoid, dan flavonoid yang terdapat pada pegagan memiliki kemampuan untuk memperbaiki sel hati dan antioksidan yang menangkap radikal bebas dalam tubuh, sehingga optimalisasi fungsi hati terjaga dan proses transaminasi dapat berjalan dengan baik.

Maka dari itu penulis tertarik untuk melakukan penelitian guna mengetahui kadar enzim transaminase (SGOT dan SGPT) dan gamma glutamyl transpeptidase $(\gamma-\mathrm{GT})$ pada ayam petelur fase layer yang diberi ekstrak pegagan, sehingga dapat menjadi kontrol optimalisasi fungsi hati supaya ternak dapat hidup sehat dan berproduksi optimal meskipun diumur tua (afkir).

\section{METODE PENELITIAN}

\section{Ternak Percobaan}

Ternak percobaan yang digunakan dalam penelitian adalah ayam petelur strain lohman brown. Fase layer menuju afkir dengan umur 119 minggu sebanyak 20 ekor. Sampel tersebut dipelihara dalam kandang tipe semi close house dengan bentuk battery individual, kandang dibuat menyusun kesamping dengan panjang $1000 \mathrm{~cm} \times$ lebar $35 \mathrm{~cm}$ x tinggi depan $42 \mathrm{~cm} \times$ tinggi belakang $37 \mathrm{~cm}$, cage yang digunakan sebanyak 20 unit. Setiap kandang berisi satu ekor ayam dilengkapi tempat pakan dan minum Penelitian ini dilaksanakan dengan menggunakan teknik rancangan acak lengkap. Terdiri dari empat (4) perlakuan penambahan pegagan dengan lima (5) kelompok ulangan, yaitu: P0 : Ransum basal tanpa penambahan ekstrak pegagan; P1 : Ransum basal $+0,04 \%$ ekstrak pegagan; $\mathrm{P} 2$ : Ransum basal $+0,08 \%$ ekstrak pegagan; P3 : Ransum basal $+0,12 \%$ ekstrak pegagan

\section{Pembuatan Ekstrak Pegagan}

Prosedur ekstraksi mengacu pada (Wahyu Sihombing., dkk 2015) Pegagan disortasi basah agar terpisah dari kotoran yang melekat, lalu dicuci sampai bersih setelah itu dikeringkan dengan cara dianginanginkan dan tidak terkena sinar matahari langsung sampai kering kira-kira selama 3 hari. Hal ini dilakukan untu menjaga sifat fisik dan kandungan kimia pegagan. Pegagan yang telah kering,digilig lalu direndam dalam etanol $70 \%$ selama 2 hari sambil diaduk. Kemudian hasil rendaman tersebut disaring pertama dengan saringan teh kemudian dilanjutkan dengan kertas saring untuk mendapatkan filtratnya. Filtrat tersebut dipisahkan dari pelarutnya dengan menggunakan rotary evaporator sampai pelarut menguap hingga diperoleh ekstrak yang kental. 


\section{Analisis Statistika}

Data respon penelitian dianalisis dengan menggunakan metode ortogonal polinomial. Suatu derajat polynomial ke-n digunakan untuk mengetahui hubungan antara peubah respon $\mathrm{Y}$ dan peubah predictor $X$ diujikan sebagai berikut :

$$
Y=\alpha+\beta_{1} X+\beta_{2} X^{2}+\ldots .+\beta_{n} X^{n}
$$

Data yang diperoleh telah dianalisis dengan software SPSS IBM 21.

\section{HASIL DAN PEMBAHASAN}

Pengaruh pemberian berbagai level ekstrak pegagan dalam pakan terhadap kadar enzyme transaminase (SGOT dan SGPT ) plasma darah ayam ras petelur, berdasarkan tinggi level pemberian ekstrak pegagan menyebabkan penurunan kadar kolesterol dengan signifikan. Hasil uji beda contras orthogonal (Tabel 1) menunjukkan rata-rata kadar kolesterol plasma darah ayam ras petelur berbeda nyata $(\mathrm{P}<0,05)$ pada berbagai kelompok perlakuan.

Pada tabal 1, tampak bahwa rata-rata kadar enzyme transaminase darah ayam ras petelur tanpa ekstrak pegagan baik kadar SGOT maupun SGPT, berbeda nyata paling tinggi $(\mathrm{P}<0,05)$ dibandingkan rata-rata kadar SGOT, SGPT darah kelompok ayam ras petelur yang diberi ekstrak pegagan. Kemudian hasil uji kontras menunjukan perbedaan rata-rata kadar SGOT dan SGPT yang nyata $(\mathrm{P}<0,05)$ juga terjadi antar kelompok ayam yang diberi perlakuan.

Tabel 1. Hasil Uji Beda Contras Orthogonal terhadap Rata-Rata Kadar SGOT dan SGPT Ayam Ras Petelur dengan Pemberian ekstrak pegagan

\begin{tabular}{|c|c|c|c|}
\hline Perlakuan & $\begin{array}{l}\text { Rata-rata perlakuan } \\
\text { SGPT(IU/L) }\end{array}$ & $\begin{array}{l}\text { Rata-rata perlakuan } \\
\text { SGOT(IU/L) }\end{array}$ & Signifikansi \\
\hline P1 & 82.13 & 45.39 & $\mathrm{a}$ \\
\hline $\mathrm{P} 2$ & 64.77 & 32,82 & $\mathrm{~b}$ \\
\hline P3 & 35.79 & 16.23 & $\mathrm{c}$ \\
\hline $\mathrm{P} 0$ & 16.23 & 9.60 & $\mathrm{~d}$ \\
\hline
\end{tabular}

Keterangan: huruf yang berbeda pada kolom signifikansi menunjukan berbeda nyata $(\mathrm{P}<0,05)$

hasil penelitian dapat dilihat pada Tabel 1 . Hasil uji polynomial orthogonal menunjukkan bahwa pemberian ekstrak pegagan berpengaruh nyata terhadap kadar enzim transaminase plasma darah ayam ras
Penurunan rata-rata kadar SGOT dan SGPT seiring dengan bertambahnya konsentrasi pemberian ekstrak pegagan dalam pakan, dapat diduga efektifitasnya melalui analisis kolerasi regresi. Persentasi

Tabel 2 Hasil Uji Beda Contras Orthogonal terhadap Rata-Rata Kadar $\gamma$-Gt Ayam Ras Petelur dengan Pemberian ekstrak pegagan

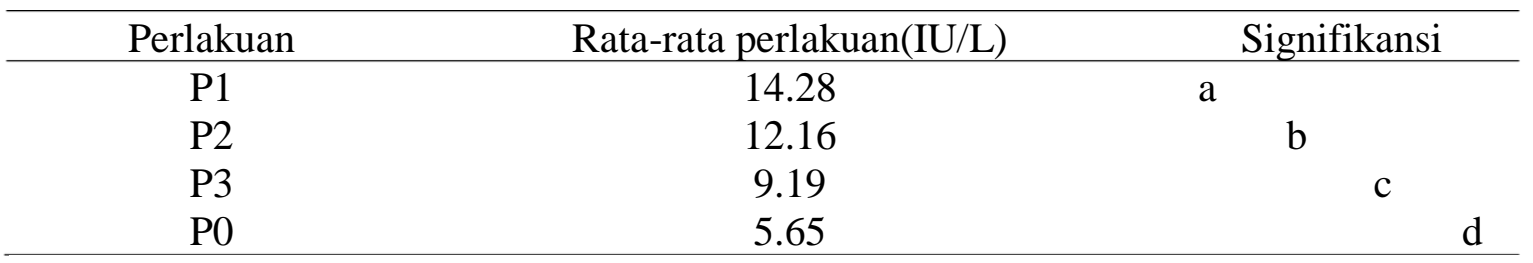

Keterangan : huruf yang berbeda pada kolom signifikansi menunjukan berbeda nyata $(\mathrm{P}<0,05)$

petelur $\quad(\mathrm{P}<0,05)$. Berdasarkan hasil penelitian menunjukkan bahwa semakin sumbangan pengaruh pegagan tehadap kadar enzime transaminase berturut turut sebesar 
$97,64 \%$ dan $86,86 \%$ atau koefisen determinasinya 0,9764 untuk kadar SGOT dan 0,8686 unutk SGPT. Terdapat derajat hubungan yang sangat tinggi antara peningkatan level pemberian ekstrak pegagan dengan penurunan kadar enzim transaminase SGOT dan SGPT dalam plasma darah, yaitu $r=0,98$ dan $r=0,93$ (Ilustrasi 1 dan 2).
SGPT. Berdasarkan model pendugaan tersebut dapat dijelaskan bahwa koefisien bernilai negatif artinya terjadi hubungan negatif antara penambahan ekstrak pegagan dengan kadar enzim dalam darah, semakin naik dosis penambahan ekstarak pegagan maka semakin turun kadar SGOT,SGPT dalam darah. Penambahan sebanyak $1 \%$

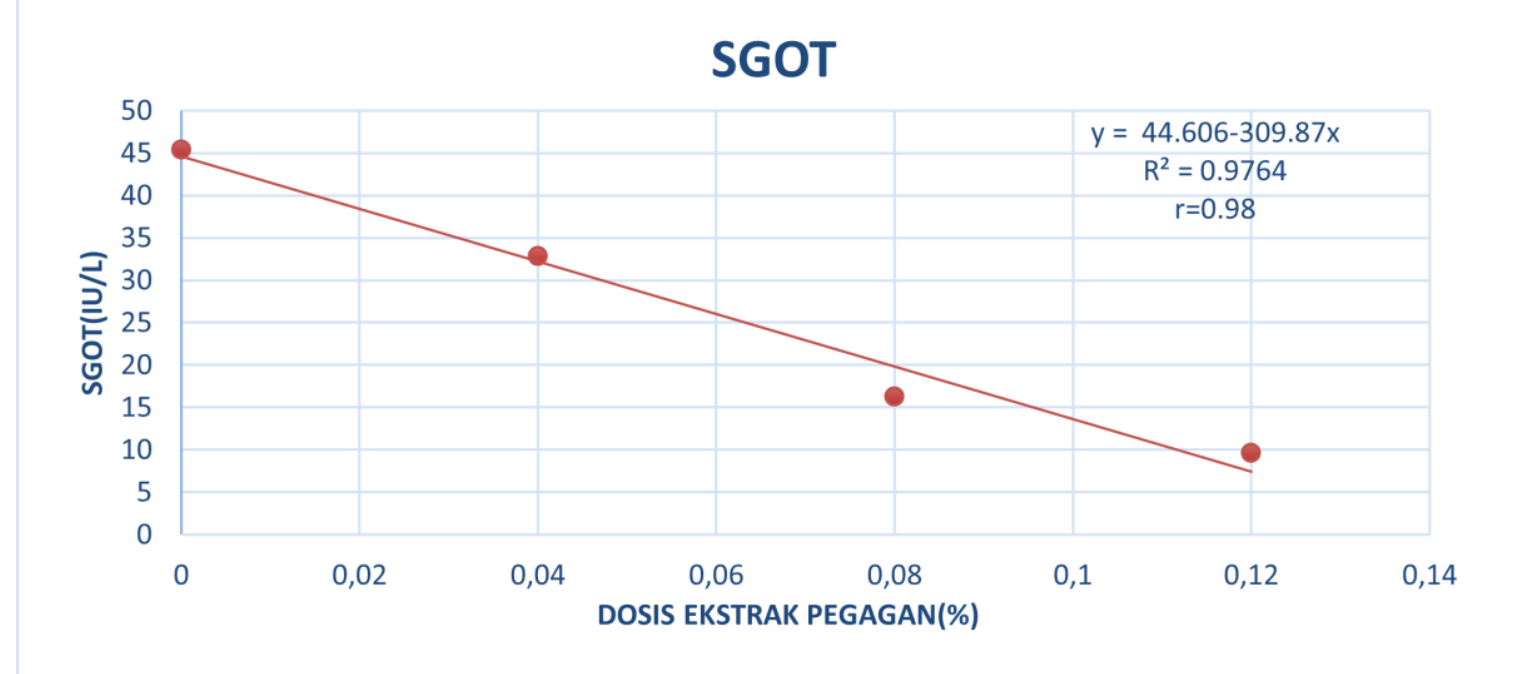

Ilustrasi 1. Grafik Analisis Kolerasi Regresi Kadar SGOT Ayam Ras Petelur dengan Pemberian Ekstrak Pegagan

Berdasarkan analisis kolerasi regresi besarnya penurunan kadar SGOT dan SGPT dapat diduga melalui persamaan atau model prediksi yaitu berturut $\mathrm{y}=44.606-309.87 \mathrm{x}$ untuk SGOT dan $\mathrm{y}=51.272-302.45 \mathrm{x}$ untuk ekstrak pegagan maka akan menurunkan nilai kadar enzyme (y) SGOT sebesar 309.87 IU/L dan SGPT 302,45 IU/L.

Sedangkan untuk pengaruh pemberian ekstrak pegagan terhadap kadar

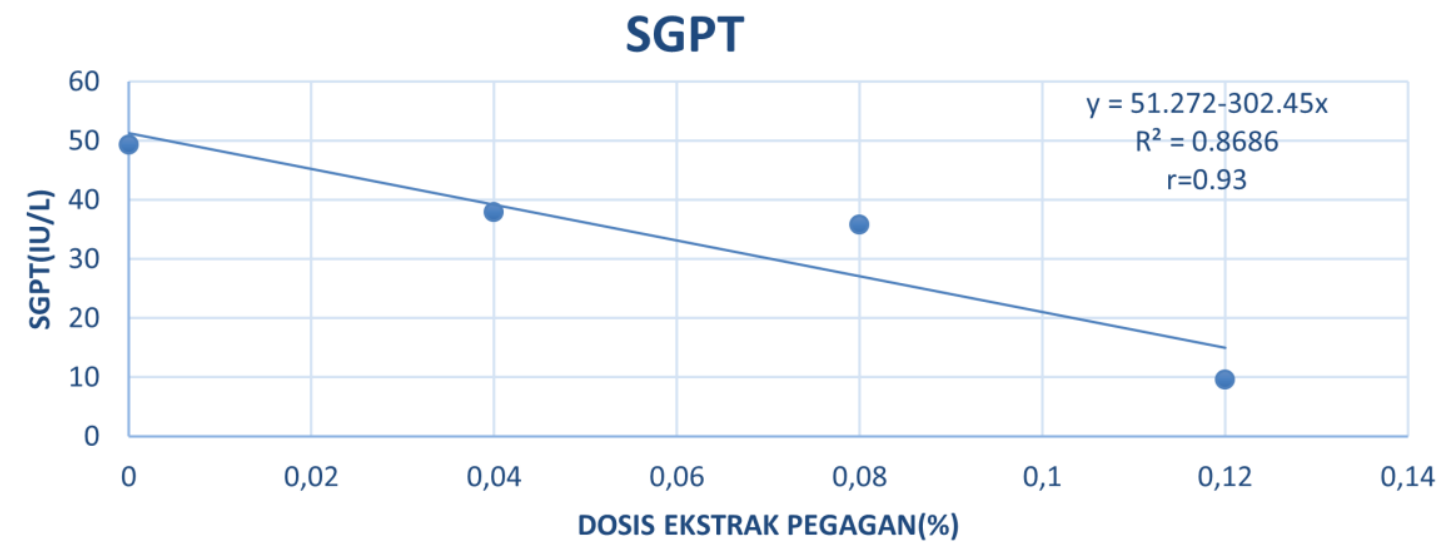

Ilustrasi 2. Grafik Analisis Kolerasi Regresi Kadar SGPT Ayam Ras Petelur dengan Pemberian Ekstrak Pegagan 
gamma glutamyl transpeptidase $(\gamma-\mathrm{Gt})$ dapat dilihat pada Tabel 2. Hasil uji polynomial orthogonal menunjukkan bahwa pemberian ekstrak pegagan berpengaruh nyata terhadap kadar enzim transaminase plasma darah ayam ras petelur $(\mathrm{P}<0,05)$.

Dari data hasil analisis yang disajikan pada tabel 7 didapatkan bahwa kadar gamma glutamyl transpeptidase $(\gamma-\mathrm{GT})$ dalam plasma darah ayam petelur yang diberi perlakuan mengalami penurunan, dari nilai kontrol (kadar enzim tanpa pelakuan) hal ini menunjukan adanya korelasi positif dari pemberian ekstrak. Perbedaan rata-rata kadar $\gamma$-GT yang nyata $(\mathrm{P}<0,05)$ juga terjadi antar kelompok ayam yang diberi perlakuan (Tabel 2).

Penurunan rata-rata kadar $\gamma$-Gt seiring dengan bertambahnya konsentrasi pemberian ekstrak pegagan, dapat diduga efektifitasnya melalui analisis kolerasi regresi. Penurunan kadar $\gamma$-Gt tersebut dipengaruhi oleh level pemberian ekstrak pegagan sebesar 93,77\% atau koefisen determinasinya 0,9377. Terdapat derajat hubungan yang sangat tinggi antara peningkatan level pemberian ekstrak pegagan dengan penurunan kadar $\gamma$-Gt plasma darah, yaitu $\mathrm{r}=0,96$ (Ilustrasi 3).

Berdasarkan analisis kolerasi regresi penambahan sebanyak $1 \%$ ekstrak pegagan menyebabkan penurunan kadar $\gamma$-Gt sebanyak 94,1 IU/L plasma darah. Kofisien bernilai negative menunjukan semakin besar pemberian ekstrak pegagan maka akan semakin menurunkan kadar $\gamma$-Gt dalam darah. Pemberian level ekstrak pegagan $0,04 \%$ dalam pakam sudah efektif untuk menurunkan kadar enzim transaminase dan $\gamma$ Gt $(\mathrm{P}<0,05)$.

Beberapa enzim yang dapat menjadi indikator kinerja hati adalah kadar enzim transaminase (SGOT, SGPT) dan gamma glutamyl transpeptidase $(\gamma-G T)$. Serum Glutamik Oksaloasetik Transaminase (SGOT) dan Serum Glutamik Pyruvik Transaminase (SGPT) merupakan dua enzim transaminase yang paling sering berkaitan dengan kerusakan hepatoselular. Ketika organ mengalami ganguan ezimenzim tersebut akan di sekresikan kedalam darah sehingga kadarnya yang tinggi dalam darah menjadi indicator adanya gangguan fungsi organ.

Gangguan fungsi hati dapat disebabkan oleh adanya stress oksidatif yang disebabkan adanya radikal bebas. Untuk mengurangi stres oksidatif yang bisa menyebabkan kerusakan hepar tubuh membutuhkan

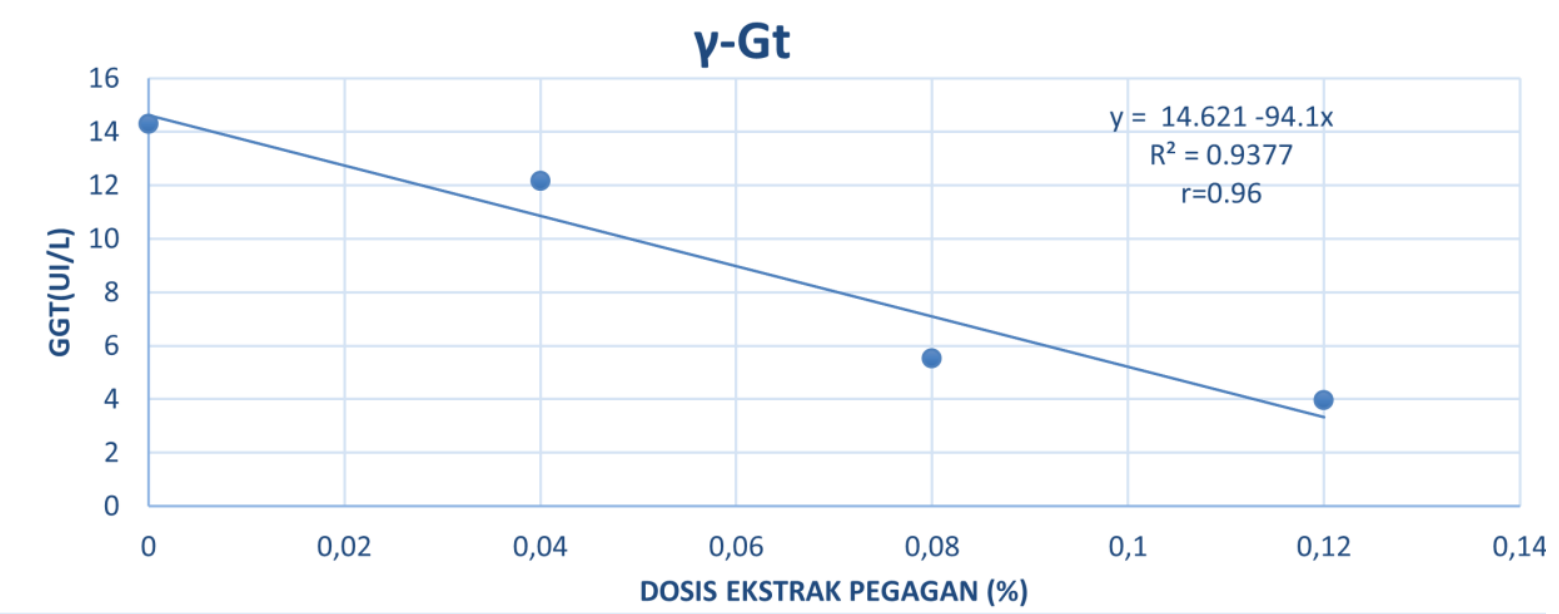

Ilustrasi 3. Grafik Analisis Kolerasi Regresi Kadar $\gamma$-Gt Ayam Ras Petelur dengan Pemberian Ekstrak Pegagan

besarnya penurunan kadar $\gamma$-Gt dapat diduga melalui persamaan atau model prediksi yaitu $\mathrm{y}=14.621 \quad-94.1 \mathrm{x} \quad$ Berdasarkan model pendugaan tersebut dapat dijelaskan bahwa antioksidan. Antioksidan diperoleh dari luar tubuh (makanan) atau diproduksi oleh tubuh sendiri (Odewabi AO, dkk 2014). Salah satu tanaman yang digunakan untuk mengobati 
penyakit hati adalah pegagan (centella asiatica) karena memiliki bahan aktif flavonoid juga mempunyai aktifitas antioksidan merupakan satu dari banyak senyawa fenol (Hastuti, 2008). Antioksidan enzim meliputi superoksida dismutase, katalase dan gluthation peroxidase (Adriani dan Mushawwir, 2020; Kamil dkk., 2020; . Sedangkan antioksidan vitamin yang dikandung oleh tanaman ini berupa vitamin $\mathrm{E}$ dan C (Latipudin dan Mushawwir, 2011, Mushawwir dkk., 2010, 2011, 2013, 2018) .

Selain itu kandungan zat aktif pegagan yaitu beberapa unsur penting yaitu centellosida, brahmosida, brahminosida serta B, C, dan D centellasaonin yang saling bekerjasama dalam proses sintesakolagen untuk meregenerasi sel dalam tubuh menormalkan fungsi sel yang rusak dan meningkatkan fungsi sel. Selain itu senyawa terpen juga dapat berfungsi sebagai peremajaan sel (Waha, 2002; Mushawwir dkk., 2019; Mushawwir dkk., 2020b,c).

Selain fungsinya sebagai antioksidan, penurunan kadar enzime ini juga dapat disebabkan karena pegagan juga dikenal sebagai antidepresan, anti-inflamasi, menyembuhkan luka, antibacterial dan hepatoprotektif (Sadiah dan mushawwir, 2015; Prakash dkk., 2017). Kandungan asam asiatik dan asiaticosida melindungi kerusakan hati oleh adanya proses fibrogenesis. Kandungan pegagan juga dapat meningkatan DNA, protein, dan kandungan kolagen dari jaringan granulasi mengakibatkan sintesis kolagen dan proliferasi sel di situs luka. sehingga degenerasi sel akan mengalami perbaikan (Tanuwiria dkk., 2020, |Mushawwir dkk., 2020a,d). Sehingga dapat disimpulkan bahwa menurunnya kadar enzim transaminase dan $\gamma$ Gt pada ayam yang diberi ekstrak pegagan memberikan pengaruh positif mempebaiki sel- sel tubuh terutama hati.

\section{KESIMPULAN}

Berdasarkan hasil penelitian disimpulkan Pemberian ekstrak pegagan dalam ransum dapat memperbaiki Enzim Transaminase dan Gamma Glutamyl
Transpeptidase $(\gamma-\mathrm{Gt})$ darah ayam ras petelur, ditunjukkan dengan penurunan kadar SGOT,SGPT dan $\gamma$-Gt plasma darah ayam ras petelur.

\section{UCAPAN TERIMA KASIH}

Penulis menyampaikan terimakasih kepada Allah SWT, orang tua, para dosen pembimbing, dan seluruh pihak yang terlibat dalam pelaksanaan penelitian dan penulisan artikel ini.

\section{DAFTAR PUSTAKA}

Adriani, L., and A. Mushawwir. 2020. Correlation between blood parameters, physiological and liver gene expression levels in native laying hens under heat stress. IOP Conf. Series: Earth and Environmental Science. 466:1-7.

Dalimartha, S. 2006. Atlas Tumbuhan Indonesia. Cetakan VIII. Trubus Agriwidaya, Jakarta.214.

Hastuti, T., 2008. Aktivitas enzim transaminase dan gambaran histopatologi hati tikus yang diberi kelapa kopyor pasca induksi parasetamol hoffman . Carophyll Pink, Nature identical astaxanthinfor aquaculture. AFAQ.

Kamil, K.A., D. Latipudin, A. Mushawwir, D. Rahmat, and R. L. Balia. 2020. The effects of ginger volatile oil (gvo) on the metabolic profile of glycolytic pathway, free radical and antioxidant activities of heat-stressed cihateup duck. International J. on Advanced Science, Engineering and Information Technology. 10:1228-1233

Latipudin, D. dan A. Mushawwir. 2011. Regulasi panas tubuh ayam ras petelur fase grower dan layer. J. Sains Peternakan Indonesia. 6:77-82.

Mushawwir, A, U.H. Tanuwiria, Kurnia Kamil, L. Adriani, R. Wiradimadja, and N. Suwarno. 2018. Evaluation of haematological responses and blood biochemical parameters of heat-stressed broilers with dietary 
supplementation of javanese ginger powder (Curcuma xanthorrhiza) and garlic extract (Allium sativum). International J. of Poultry Sci. 17:452-458.

Mushawwir, A. dan D. Latipudin. 2013. Biologi Sintesis Telur : Perspektif Fisiologi, Biokimia dan Molekuler Produksi Telur. Graha Ilmu, Yogyakarta.

Mushawwir, A. Y.K. Yong, L. Adriani, E. Hernawan, and K.A. Kamil. 2010. The Fluctuation Effect of Atmospheric ammonia (NH3) Exposure and Microclimate on Hereford Bulls Hematochemical. J. of the Indon Tropical Anim Agric. 35:232-238.

Mushawwir, A., L.Adriani, and K.A. Kamil. 2011. Prediction models for olfactory metabolic and sows\% RNAreticulocyt (RNArt) by measurement of atmospheric ammonia exposure and microclimate level. J. of the Indon Tropical Anim Agric. 36:14-20.

Mushawwir, A., N. Suwarno, A.A. Yulianti. 2019. Profil malondialdehyde (MDA) dan kreatinin itik fase layer yang diberi minyak atsiri garlic dalam kondisi cekaman panas. Jurnal Ilmu dan Industri Peternakan 5 (1):1-11.

Mushawwir, A., A.A. Yulianti, N. Suwarno, dan R. Permana. 2020a. Profil metabolit plasma darah dan aktivitas kreatin kinase sapi perah berdasarkan fluktuasi mikroklimat lingkungan kandangnya. J. Veteriner. 21:24-30.

Mushawwir, A., A.A. Yulianti, dan N. Suwarno. 2020b. Histologi liver burung puyuh dengan pemberian minyak atsiri bawang putih. J. Ilmu dan Teknologi Peternakan. 8:1-7.

Mushawwir, A., N. Suwarno, dan D. Latipudin. 2020c. Profil metabolik jalur glikogenolisis puyuh dalam kondisi stres panas dengan pemberian diallyl n-sulfida (dn-s) organic. J. Galung Tropika. 9:48-59.

Mushawwir, A., N. Suwarno, dan R. Permana. 2020d. Profil non-esterified fatty acids (NEFA) dan trigliserida ayam sentul pada sistem pemeliharaan berbeda. J. Ilmu dan Industri Peternakan. 6:14-24.

Odewabi, A.O., O.A. Ogundahunsi, and M. Oyalowo. 2014. Effect of exposure to petroleum fumes on plasma antioxidant defense system in petrol attendants. Br. J. Pharmacol. Toxicol. 5:83-88.

Prakash Ved, Nishita, Mrinal. 2017. A review on medicinal properties of centtela Asiatica., India. Depatement biotechnology national institute technologi.

Sadiah, I. N., dan A. Mushawwir. 2015. Mortalitas embrio dan daya tetas itik lokal (Anas sp.) berdasarkan pola pengaturan temperatur mesin tetas. Students e-Journal. 4:32-39.

Sihombing, W. 2015. Efek Ekstrak Daun Pegagan (Centella Asiatica (L.) Urban) terhadap perkembangan sel spermatid tikus. J. Veterania Medika. 4:72-79

Tanuwiria, U.H., D. Tasrifin, dan A. Mushawwir. 2020. Respon gamma glutamil transpeptidase $(\gamma$-gt) dan kadar glukosa sapi perah pada ketinggian tempat (altitude) yang berbeda. J. Ilmu dan Industri Peternakan. 6:25-34.

Waha, M.G. 2001. Sehat dengan mengkudu. MSF Group,Jakarta. Hal 1-44. 